\title{
Evaluation of Four Variants of the Thyroid Imaging Reporting and Data System (TIRADS) Classification in Patients with Multinodular Goitre - initial study
}

\author{
Ocena czterech wariantów klasyfikacji TIRADS w grupie pacjentów \\ z wolem guzkowym — badanie wstępne
}

\author{
Bartosz Migda', Michal Migda ${ }^{2}$, Anna M. Migda ${ }^{3}$, Jacek Bierca ${ }^{4}$, Jadwiga Slowinska-Srzednicka ${ }^{5}$, \\ Wieslaw Jakubowski ${ }^{1}$, Rafal Z. Slapa ${ }^{1}$
}

${ }^{1}$ Department of Diagnostic Imaging, Second Faculty of Medicine with the English Division and the Physiotherapy Division, Medical University of Warsaw, Poland

${ }^{2}$ United District Hospital, Collegium Medicum, University of Nicolaus Copernicus, Clinical Unit of Obstetrics, Women's Disease and Gynecological Oncology, Torun, Poland

${ }^{3}$ First Department of Internal Diseases, Bielanski Hospital, Warsaw, Poland

${ }^{4}$ Surgery Department, Solec Hospital, Warsaw, Poland

${ }^{5}$ Department of Endocrinology, Centre for Postgraduate Medical Education, Warsaw, Poland

\begin{abstract}
Introduction: The aim of this study was to evaluate the usefulness of four variants of the Thyroid Imaging Reporting and Data System (TIRADS) in the differentiation of focal lesions in individuals with multinodular goitre.

Materials and methods: The study was approved by the Local Bioethical Committee. Each patient gave informed consent before enrolment. A total of 163 nodules in 124 patients with multinodular goitre were evaluated by ultrasound. B-mode and PD imaging and strain elastography were performed. Archived images were evaluated via retrospective analysis using four different proposed TIRADS classifications. Results: Sensitivity and specificity of the Horvath, Park, Kwak, and Russ classifications were 0.625 and $0.769,0.813$ and $0.864,0.938$ and 0.667 , and 0.875 and 0.293 , respectively. Positive and negative predictive values were 0.227 and $0.95,0.394$ and $0.977,0.234$ and 0.99 , and 0.119 and 0.956 , respectively. Receiver operating characteristic analysis suggests that the best differentiation potential was demonstrated by the Kwak classification with an area under the curve (AUC) of 0.896 , followed by the Park (AUC $=0.872$ ), Horvath $($ AUC $=0.774)$, and Russ (AUC $=0.729$ ) classifications.

Conclusions: The TIRADS classification proposed by Kwak can be a useful tool in daily practice for the evaluation of thyroid cancer in individuals with multinodular goitre, particularly for selecting cases that require biopsy, which may improve and simplify clinical decision making. To adopt a definitive, comprehensive variant of the TIRADS classification with potential for universal, practical application, further prospective studies that include improvement of the lexicon and evaluation of the full spectrum of thyroid malignancy are warranted. (Endokrynol Pol 2018; 69 (2): 156-162)
\end{abstract}

Key words: thyroid; nodular goitre; ultrasound; elastography; thyroid imaging reporting and data system

\begin{abstract}
Streszczenie
Wstęp: Celem tej pracy była ocena przydatności 4 wariantów systemu raportowania badań ultrasonograficznych tarczycy (TIRADS) do różnicowania zmian ogniskowych u pacjentów z wolem guzkowym.

Materiał i metody: Badanie było zatwierdzone przez właściwą komisję bioetyczną. Każdy pacjent wyraził świadomą zgodę przed przystąpieniem do badania. W badaniu ultrasononograficznym analizowano 163 zmiany ogniskowe u 124 pacjentów z wolem guzowatym. Wykonano obrazowanie w skali szarości, z dopplerem mocy oraz elastografię odkształceń względnych. Zarchiwizowane obrazy zostały poddane analizie retrospektywnej z zastosowaniem 4 wariantów klasyfikacji TIRADS.

Wyniki: Czułość i swoistość klasyfikacji Horvath, Park, Kwak i Russ wyniosły odpowiednio 0,625 i 0,769, 0,813 i 0,864, 0,938 i 0,667 oraz 0,875 i 0,293. Dodatnie i ujemne wartości predykcyjne wynosily odpowiednio 0,227 i 0,95, 0,394 i 0,977, 0,234 i 0,99 oraz 0,119 i 0,956. Analiza ROC sugeruje, że najlepszy potencjał w różnicowaniu prezentuje wariant Kwak z polem pod krzywą (AUC) of 0,896, następnie Park (AUC $=0,872)$, Horvath (AUC $=0,774)$ i Russ (AUC $=0,729)$.

Wnioski: Klasyfikacja TIRADS proponowana przez Kwaka może być przydatnym narzędziem w codziennej praktyce oceny pod kątem raka tarczycy u pacjentów z wolem guzkowym, szczególnie do wyselekcjonowania przypadków wymagających biopsji, co może polepszyć i uprościć podjęcie decyzji klinicznej. Wskazane są dalsze badania prospektywne, obejmujące ulepszenie leksykonu i ocenę pełnego spektrum guzów złośliwych tarczycy, aby ostatecznie przyjąć optymalny wariant klasyfikacji TIRADS, co zapewne umożliwi jej uniwersalne praktyczne zastosowanie. (Endokrynol Pol 2018; 69 (2): 156-162)
\end{abstract}

Słowa kluczowe: tarczyca; wole guzkowe; ultrasonografia; elastografia; TIRADS

Bartosz Migda, Department of Diagnostic Imaging, Second Faculty of Medicine with the English Division and the Physiotherapy Division, Medical University of Warsaw, Poland, mobile phone: +48607398361, phone: +48223265810, fax:+48223265479, e-mail: bartoszmigda@gmail.com 


\section{Introduction}

Ultrasound imaging significantly increased the number of focal thyroid lesions detected, with the percentage reaching as high as $67 \%$ of the population [1]. However, the percentage of malignant lesions in this cohort is less than $10 \%$, regardless of whether the detected lesions are solitary nodules or in a multinodular goitre $[2,3]$. At present, there is no common system for risk stratification of thyroid nodules based on ultrasound images although several classification strategies have been proposed. The present study examines these strategies.

Systematic categorisation of focal thyroid lesions by risk of malignancy has been performed for the last eight years. The goal of this categorisation is to improve communication with clinicians for the purpose of nodule management via imaging follow-up, cytological analysis, or pathological verification.

The Thyroid Imaging Reporting and Data System (TIRADS) was initially presented in 2009 by two independent teams $[4,5]$. TIRADS refers to the well-known and widely applied Breast Imaging Reporting and Data System (BIRADS) used to describe focal breast lesions in X-ray mammography, magnetic resonance mammography, and ultrasound imaging to estimate malignancy risk and the need for further diagnostic management [6].

Among numerous published studies, four variants of TIRADS classification $[4,5,7,8]$ have been widely analysed by research teams [9-14], with findings indicating a high potential for the differentiation of thyroid nodules. Despite the literature evaluating the diagnostic parameters of these classification systems, to our knowledge there is no such evaluation in patients with multinodular goitre. Such patients pose a serious challenge to the investigator due to the frequent complexity of ultrasound images. As such, recommendation of the lesions for further cytological verification or ultrasound follow-up is difficult.

The goal of the present study was to evaluate the utility of the four variants of TIRADS classification proposed by Horvath, Park, Kwak, and Russ et al. for the differentiation of focal lesions in individuals with multinodular goitre.

\section{Material and methods}

We conducted a retrospective analysis of images obtained from 124 consecutive patients with multinodular goitre, who were referred for thyroidectomy because of compression symptoms, cosmetic defects, suspicion of thyroid cancer, or hormonal disorders. The group consisted of 110 women and 14 men. Analysis of this material and procedure was previously described [15]. During an ultrasound examination the dominant nodules, based on ultrasound features, were selected [15]. A total of 163 dominant nodules, including 16 papillary cancers, were evaluated. The mean age of the women was 54 years (range 24-78) and the mean age of the men was 57 years (range 23-79). Analysis of ultrasound data included application of four TIRADS classifications. The study involved patients with multinodular goitre, who were scheduled for thyroidectomy (because of: compression symptoms, cosmetic defect, diagnosis or suspicion of malignancy, and hormonal imbalance). Selection of the suspicious nodules for the analysis with ultrasound techniques (B-mode, Power Doppler, strain elastography) included any combination of the following thyroid nodule ultrasound suspicious features: shape taller than wide, low echogenicity, irregular margins, high echogenicity foci, and dominant nodule by ultrasound features in the ultrasound presentation of nodular goitre [16-18]. In each case, the diagnosis was ultimately based on histopathological examination.

\section{Horvath TIRADS [4]}

The Horvath method of TIRADS classification was based on 10 thyroid nodule ultrasound patterns, based on B-mode and Power Doppler (PD). A specific TIRADS category was assigned to each nodule depending on the particular ultrasound pattern (Table I). Patterns distinguished included three types of colloidal lesions, a nodule in the course of Hashimoto disease, simple neoplastic pattern with thin borders, a nodule in the course of de Quervain disease, a suspected neoplastic pattern, and three malignant patterns (A, B, and C) where $C$ is a pattern of cancer confirmed by cytology.

\section{Park TIRADS [5]}

The Park method of TIRADS classification uses five categories (TUS 1-5), where each category is based on the formula below:

$$
\mathrm{P}^{\mathrm{US}}=1 /\left(1+\mathrm{e}^{-\mathrm{z}}\right)
$$

where $\mathrm{e}=2.71828 \ldots$, and " $\mathrm{z}$ " is calculated using the following equation accounting for numerous nodule characteristics:

$\mathrm{Z}=-2.862+0.581 \mathrm{X}_{1}-0.481 \mathrm{X}_{2}-1.435 \mathrm{X}_{3}+$ $1.178 \mathrm{X}_{4}+1.405 \mathrm{X}_{5}+0.700 \mathrm{X}_{6}+0.648 \mathrm{X}_{8}-1.715 \mathrm{X}_{9}$ $+0.463 \mathrm{X}_{10}+1.964 \mathrm{X}_{11}+1.739 \mathrm{X}_{12}$ where $\mathrm{X}_{1} \ldots \mathrm{X}_{12}$ are defined as follows:

$X_{1}$ shape: taller $=1$, wider $=0$

$X_{2}$ perinodular halo: presence $=1$, absence $=0$

$X_{3}$ well-circumscribed: presence $=1$, absence $=0$

$\mathrm{X}_{4}$ microlobulation: presence $=1$, absence $=0$

$X_{5}$ infiltrative margin: presence $=1$, absence $=0$

$\mathrm{X}_{6}$ marked hypoechoic: presence $=1$, absence $=0$

$\mathrm{X}_{8}$ hypoechoic: presence $=1$, absence $=0$

$X_{9}$ homogeneous echotexture: presence $=1$, absence $=0$

$X_{10}$ solid: presence $=1$, absence $=0$ 
Table I. Ultrasound characteristics of thyroid nodules; 10 ultrasound patterns with associated malignancy risk and TIRADS category proposed by Horvath [4]

Tabela I. Ultrasonograficzna charakterystyka guzków tarczycy; 10 wzorców ultrasonograficznych związanych z ryzkiem złośliwości i klasyfikacja TIRADS zaproponowanq przez Horvath [4]

\begin{tabular}{|c|c|c|c|}
\hline Description of ultrasound pattern & Ultrasound patterns & Malignancy risk & TIRADS category \\
\hline Anechoic with hyperechoic spots, non-vascularised lesion & Colloid type 1 & $0 \%$ & TIRADS 2: benign finding \\
\hline $\begin{array}{l}\text { Non-encapsulated, mixed, non-expansile, with hyperechoic } \\
\text { spots, vascularized lesion, „grid” aspect (spongiform nodule) }\end{array}$ & Colloid type 2 & & \\
\hline $\begin{array}{l}\text { Non-encapsulated, mixed with solid portion, isoechogenic, } \\
\text { expansile, vascularised nodule with hyperechoic spots }\end{array}$ & Colloid type 3 & & \\
\hline $\begin{array}{l}\text { Hyper, iso, or hypoechoic, partially encapsulated nodule with } \\
\text { peripheral vascularization, in Hashimoto's thyroiditis }\end{array}$ & Hashimoto pseudonodule & $<5 \%$ & $\begin{array}{l}\text { TIRADS 3: probably } \\
\text { benign }\end{array}$ \\
\hline Solid or mixed hyper, iso, or hypoechoic nodule, with thin capsule & Simple neoplastic pattern & $5-10 \%$ & TIRADS 4a: undetermined \\
\hline Hypoechoic lesion with ill-defined borders, without calcifications & de Quervain pattern & & \\
\hline $\begin{array}{l}\text { Hyper, iso, or hypoechoic, hypervascularised, encapsulated } \\
\text { nodule with a thick capsule, containing calcifications (coarse or } \\
\text { microcalcifications) }\end{array}$ & suspicious neoplastic pattern & & \\
\hline $\begin{array}{l}\text { Hypoechoic, non-encapsulated nodule, with irregular shape and } \\
\text { margins, penetrating vessels, with or without calcifications }\end{array}$ & Malignant pattern A & $10-80 \%$ & TIRADS 4b: suspicious \\
\hline $\begin{array}{l}\text { Iso or hypoechoic, non-encapsulated nodule with multiple } \\
\text { peripheral microcalcifications and hypervascularisation }\end{array}$ & Malignant pattern B & $>80 \%$ & $\begin{array}{l}\text { TIRADS 5: consistent with } \\
\text { malignancy }\end{array}$ \\
\hline $\begin{array}{l}\text { Non-encapsulated, isoechoic mixed hypervascularised nodule } \\
\text { with or without calcifications, without hyperechoic spots }\end{array}$ & $\begin{array}{l}\text { Malignant pattern } \mathrm{C} \text {, Cancer } \\
\text { confirmed by previous biopsy }\end{array}$ & $100 \%$ & TIRADS 6: malignant \\
\hline
\end{tabular}

$\mathrm{X}_{11}$ microcalcification: presence $=1$, absence $=0$

$X_{12}$ lymph node: abnormal $=1$, normal $=0$

TUS category is defined by the $\mathrm{P}^{\mathrm{US}}$ value as defined below:

TUS 1 if Pus lower than 0.07

TUS 2 if Pus lower than 0.23

TUS 3 if Pus range from 0.24 to 0.5

TUS 4 if Pus range from 0.51 to 0.9

TUS 5 if Pus range from 0.91 to 1.0

\section{Kwak TIRADS [7]}

The Kwak method of TIRADS classification is dependent on a number of suspicious features, such as solid nodule, low or very low echogenicity (if the nodule echogenicity was less than the surrounding strap muscles), irregular or lobular margins, microcalcifications, and vertical nodule shape (taller than wide). The number of suspicious features is used to classify each nodule: TIRADS $3-0$ (no suspicious features), TIRADS $4 \mathrm{a}-1$ (one suspicious feature), TIRADS $4 \mathrm{~b}-$ 2 (two suspicious features), TIRADS $4 \mathrm{c}-3$ or 4 (three or four suspicious features), and TIRADS $5-5$ (five suspicious features).

\section{Russ TIRADS [8]}

The Russ method of TIRADS classification consists of five categories (1-5), where category 4 is subdivided in $4 \mathrm{a}$ and $4 \mathrm{~b}$. The assignment of a nodule to each category is based on the features described in Table II.
The Russ TIRADS classification was the first to include elastography. As such, we also used strain elastography to evaluate the utility of this method. However, as in the original paper, due to the poor reproducibility of elasticity index (EI), strain ratio (SR) was used in the analysis.

\section{Equipment}

Examinations were performed with a Toshiba Aplio XG scanner (Japan), with a high-frequency (7-18 MHz) linear transducer. Classical B-mode imaging was enriched by spatial compound imaging and differential tissue harmonics. The examination also included Power Doppler (PD) imaging. For evaluation of the Russ TIRADS classification, which relies on elastography, images obtained on strain elastography and strain ratio were used.

\section{Statistical analysis}

Statistical analysis was performed using the original statistical program STATISTICA 10 (StatSoft Inc.). For each classification, descriptive measures [sensitivity, specificity, positive predictive value (PPV), negative predictive value (NPV), accuracy, and risk ratio with 95\% confidence interval] were calculated and results are shown in Table III. Receiver operating characteristic (ROC) curves were used to assess the diagnostic value of each TIRADS classification, giving an area under the curve (AUC) value with 95\% confidence interval (CI) and associated significance level ( $p$-value). Area under the ROC curves was compared for each classification 
Table II. Ultrasound patterns with TIRADS classification proposed by Russ [8]

Tabela II. Ultrasonograficzna charakterystyka klasyfikacji TIRADS zaproponowanej przez Russ [8]

\begin{tabular}{|c|c|c|c|c|}
\hline Benign Patterns & & Suspect Patterns & & \\
\hline Constantly & Probably & Mildly suspect & \multicolumn{2}{|l|}{ Highly suspect } \\
\hline Simple cyst & No sign of high suspicion & No sign of high suspicion & \multicolumn{2}{|c|}{ Taller-than-wide, Irregular border } \\
\hline Spongiform nodule & Regular shape and borders & Mildly hypoechoic & \multicolumn{2}{|c|}{ Microcalcifications, Markedly hypoechoic } \\
\hline 'white knight' & No microcalcifications & & \multicolumn{2}{|c|}{ High stiffness with sonoelastography (if available) } \\
\hline Isolated macrocalcification & and & & One or two signs & Three to five signs and/or \\
\hline 'nodular hyperplasia' & Isoechoic or Hyperechoic & & No metastatic lymph node & Metastatic lymph node \\
\hline TIRADS 2 & TIRADS 3 & TIRADS 4a & TIRADS 4b & TIRADS 5 \\
\hline
\end{tabular}

'white knight' — representative of numerous hyperechoic round pseudo-nodules with no halo or central vascularisation; 'nodular hyperplasia' — representative of isoechoic confluent micronodules located within the inferior and posterior portion of one or two lobes usually avascular and seen in simple goitres [8]

Table III. Statistical analysis of four TIRADS classification variants in multinodular goitre

Tabela III. Analiza statystyczna czterech klasyfikacji u chorych z wolem guzkowym

\begin{tabular}{llllllll}
\hline Classification & Sensitivity & Specificity & PPV & NPV & ACC & RR & 95\% CI \\
\hline Horvath & 0.625 & 0.769 & 0.227 & 0.95 & 0.755 & 4.5 & $1.547-13.136$ \\
\hline Park & 0.813 & 0.864 & 0.394 & 0.977 & 0.859 & 17.1 & $4.596-63.41$ \\
\hline Kwak & 0.938 & 0.667 & 0.234 & 0.99 & 0.693 & 23.2 & $2.991-179.977$ \\
\hline Russ & 0.875 & 0.293 & 0.119 & 0.956 & 0.35 & 2.7 & $0.583-12.216$ \\
\hline
\end{tabular}

$P P V$ - positive predictive value, $N P V$ - negative predictive value, $A C C$ - accuracy, $R R$ - risk ratio, $\mathrm{Cl}$ - confidence interval

system to determine whether results differed. For all analyses, $\mathrm{p}<0.05$ was considered significant.

\section{Results}

\section{Descriptive statistics}

Sensitivity and specificity of the Horvath, Park, Kwak, and Russ TIRADS classifications were 0.625 and 0.769 , 0.813 and $0.864,0.938$ and 0.667 , and 0.875 and 0.293 , respectively. PPV and NPV of the Horvath, Park, Kwak, and Russ TIRADS classifications were 0.227 and 0.95 , 0.394 and $0.977,0.234$ and 0.99 , and 0.119 and 0.956 , respectively. The highest level of diagnostic accuracy was observed with the Park TIRADS classification (0.859) followed by Horvath (0.755), Kwak (0.693), and Russ (0.35). Risk ratio was highest using the Kwak TIRADS classification (23.1, 95\% CI 2.991-179.977) and Park TIRADS classification (17.1, 95\% CI 4.596-63.41). Values were much lower for the remaining classifications with a risk ratio of 4.5 (95\% CI 1.457-13.136) for the Horvath TIRADS classification and 2.7 (95\% CI 0.583-12.216) for the Russ TIRADS classification (Table III).

\section{ROC analysis}

In further analysis, values of area under the ROC curves were compared to determine whether the results for each classification differed. In all cases, the results
Table IV. Receiver operating characteristic (ROC) curve analysis of four TIRADS classification variants in multinodular goitre

Tabela IV. Analiza krzywych ROC dla czterech klasyfikacji TIRADS

\begin{tabular}{llll}
\hline ROC & AUC & 95\% Cl & p-value \\
\hline Horvath & 0.774 & $0.667-0.881$ & $<0.0001$ \\
\hline Park & 0.872 & $0.766-0.979$ & $<0.0001$ \\
\hline Kwak & 0.896 & $0.792-0.999$ & $<0.0001$ \\
\hline Russ & 0.729 & $0.617-0.841$ & $<0.0001$ \\
\hline
\end{tabular}

ROC - receiver operator characteristic, AUC — area under the ROC curve, $\mathrm{Cl}$ - confidence interval

were significant $(\mathrm{p}<0.0001$, Table IV). The greatest differentiation potential was observed with the Kwak TIRADS classification (AUC $=0.896,95 \%$ CI 0.792-0.999) followed by Park (AUC $=0.872,95 \%$ CI 0.766-0.979), Horvath (AUC $=0.774,95 \%$ CI 0.667-0.881), and Russ (AUC $=0.729,95 \%$ CI 0.617-0.841) (Table IV). Results of the ROC curves for the tested TIRADS classifications were compared in all combinations (Table V). Results for the Kwak TIRADS classification were significantly different from results for the Horvath $(p=0.0268)$ and Russ ( $p=0.0044)$ TIRADS classifications. Moreover, significant differences were observed between the Park 
Table V. Receiver operating characteristic (ROC) curve crosscomparison of four TIRADS classification variants applied to multinodular goitre

Tabela V. Porównanie krzywych ROC między kolejnymi klasyfikacjami TIRADS

\begin{tabular}{ll}
\hline AUC comparison & p-value \\
\hline Kwak vs. Park & 0.4464 \\
\hline Kwak vs. Horvath & 0.0268 \\
\hline Kwak vs. Russ & 0.0044 \\
\hline Horvath vs. Russ & 0.2977 \\
\hline Park vs. Horvath & 0.0622 \\
\hline Park vs. Russ & 0.0023 \\
\hline
\end{tabular}

AUC — area under the ROC curve

and Russ TIRADS classifications ( $\mathrm{p}=0.0023)$. There were no differences between results for the Kwak and Park $(\mathrm{p}=0.4464)$, Park and Horvath $(\mathrm{p}=0.0622)$, and Horvath and Russ $(p=0.2977)$ TIRADS classifications.

\section{Discussion}

Numerous ultrasound techniques, such as classic B-mode, Power, and Color Doppler imaging, as well as newer techniques, such as elastography and contrastenhanced ultrasound, have been investigated for their ability to differentiate thyroid nodules. However, recent studies indicate that the most valuable in this regard is B-mode ultrasound [15, 19-22]. Additionally, grey-scale imaging of focal lesions is simpler and cheaper than newer techniques, which require greater experience, more expensive equipment, and, in cases where microvascularisation is assessed, additional costs associated with the contrast agent. Unfortunately, a unified lexicon that clearly categorises tumour malignancy risk based on ultrasound features and provides guidelines for further decision making regarding routine follow-up or cytological or histological verification is missing. As such, the combination of cytological evaluation, with its limitations, and ultrasound continue to be used as basic diagnostic tools [14, 23]. Several different versions of TIRADS classification have been described in the literature, although only four such tools have been examined extensively enough to serve as a starting point for the present analysis.

Horvath et al. [4] published the first prospective study to cite 10 ultrasonographic patterns of focal thyroid lesions. Unfortunately, these standards do not cover the entire spectrum of lesions that may be present in thyroid nodules, especially multinodular goitre, making this classification more difficult to use in daily practice. Importantly, the results presented by Horvath differed from those obtained in the present study. Sensitivity, PPV, and accuracy were lower 0.625 vs. $0.88,0.227$ vs. 0.49 , and 0.775 vs. 0.94 , respectively. In contrast, specificity and NPV were higher at 0.769 vs. 0.49 and 0.95 vs. 0.88 , respectively. The same year, a second retrospective study from Park et al. was presented [5] proposing use of a formula for calculation of TIRADS classification. Despite similar promising diagnostic parameters in the original paper and our study (sensitivity 0.813, specificity 0.864, PPV 0.394, NPV 0.977, and diagnostic accuracy 0.859 ), the formula proves too complicated for use in daily practice. A retrospective study published by Kwak et al. presented a more practical and interesting approach for TIRADS classification based on analysis of suspicious ultrasonographic features of thyroid nodules [7]. Diagnostic parameters in multinodular goitres using the Kwak TIRADS classification in our study were as follows: sensitivity 0.938 , specificity 0.667 , PPV 0.234 , NPV 0.99, and diagnostic accuracy 0.693. Kwak et al. also noted that solid nodules that were considered suspicious actually had a low malignancy risk (0.036), while lesions presenting microcalcifications or lobular margins had a higher malignancy risk (0.109 and 0.127, respectively). Additionally, the presence of microcalcifications or lobular margins alone had a higher malignancy risk compared to solid or hypoechogenic nodules (0.068-0.093), making this method limited by a potential increase in the percentage of false positive cases.

The final TIRADS classification analysed was presented by Russ et al. [8] and included four suspicious ultrasonographic features initially proposed by Kim et al. [16] with the addition of a fifth element, namely solid structure and mild hypoechogenicity (defined as more hypoechoic than the surrounding gland but less than strap muscles [8]). It is also the only classification that includes optional elastography. In our study and the original publication, strain elastography was used. Data from our analysis compared to the original results are as follows: sensitivity 0.875 vs. 0.957 (B-mode) and 0.985 (B-mode + elastography), specificity 0.293 vs. 0.61 (B-mode) and 0.447 (B-mode + elastography), PPV 0.119 vs. 0.06 (B-mode) and 0.016 (B-mode + elastography), NPV 0.956 vs. 0.997 (B-mode) and 0.998 (B-mode + elastography), and diagnostics accuracy 0.35 vs. 0.62 (B-mode) and 0.483 (B-mode + elastography). It was disappointing to find that TIRADS classification with elastography fared worse than classification based on B-mode as presented in Table III and reported previously by Moon et al. and Migda et al. [15, 24]. These authors showed clearly that grey-scale with elastography has poorer results for distinguishing benign from malignant nodules compared to single grey-scale assessment. Unluturk et al. also suggested a lower sensitivity and specificity for elastography to discriminate 
benign from malignant thyroid lesions [25], unlike in other publications $[26,27]$. On contrary to these works, Gietka et al. and Wolinski et al. suggested the usefulness of real-time elastography (RTE) and shear wave elastography (SWE), respectively, in selecting nodules to FNAB $[28,29]$.

Ultimately, the best classifications of multinodular goitres proved to be those presented by Park and Kwak with TIRADS AUCs of 0.872 and 0.896 , respectively. The first classification (Park) has better specificity, PPV, and diagnostic accuracy and gives lower false positive rate, which could potentially decrease rates of unnecessary biopsies. On the other hand, the Kwak classification had higher sensitivity and NPV and a lower rate of false negative results, which could potentially lower the rate of missed malignancies (Table III). Poorer results of the TIRADS variant including elastography may be related to the features of multiple nodules in multinodular goitre. The heterogeneous elasticity of the whole thyroid gland due to multiple nodules may influence the elasticity index and elasticity strain ratio of the evaluated dominant nodules.

Comparison of the diagnostic utility of the TIRADS variants based on ROC parameters indicates that Kwak TIRADS classification results differ from those presented by the Russ and Horvath TIRADS classifications, but it does not differ from the Park TIRADS classification. Park TIRADS classification results differ significantly from the Russ TIRADS classification, suggesting that the Kwak and Park TIRADS classifications provide better discrimination of thyroid nodules in multinodular goitre (Table V).

It is important to note that there is no available unified and universal lexicon describing focal thyroid lesions. Cited authors used generally known naming, but some differences were present. For example, in the case of hypoechogenicity, terminology is uncertain. Kim suggested that a lesion is "very hypoechogenic" when echogenicity is lower than the echogenicity of strap muscles. Park et al., Russ et al., and Kwak et al. used the same definition, but relative echogenicity comparison depends on muscles structures. It can differ and depends on age group. Furthermore, "mildly echogenic" as proposed by Russ is sometimes controversial and questions remain regarding where the border between hypoechogenic, mildly hypoechogenic, and very hypoechogenic lies. The literature also delivers many definitions for microcalcifications, such as tiny, punctate hyperechoic foci with or without acoustic shadows [16]; round, sometimes linear, and tiny punctuations [8]; and hyperechoic foci $<0.5 \mathrm{~mm}$ diameter without acoustic shadowing [5]. As such, none of the evaluated classifications was based on an approved and generally accepted lexicon for focal thyroid lesions. In 2015, the
American College of Radiology proposed a lexicon for reporting thyroid focal lesions [30], which to date has not been used in any publications regarding TIRADS. Such standardisation of reports may in the future enable more precise comparison across studies.

This study has some limitations. First, this is a retrospective study. Second, there was relatively small number of lesions, with significantly small number of malignancies. However, the percentage of malignancies in the study is compatible with the percentage of malignancies usually found in the population with multinodular goitre. Nonetheless, this study needs further evaluation in a larger group of nodules.

Additionally, we could not exclude patient selection bias as it was necessary to have a final histological result, but we found it ethically inappropriate to qualify patients with cytologically confirmed benign lesion without any other clinical indications for thyroidectomy. Fourth, study restrictions precluded analysis of nodules other than those dominant by ultrasound features. However, from a practical point of view, such selection is the only practical solution and is advocated by numerous guidelines $[18,31,32]$. This approach resulted in the identification of all cancers with foci larger than $3 \mathrm{~mm}$ in diameter on histopathology examination from the entirety of the multinodular goitre material. Fifth, this study did not include any type of thyroid cancers other than the most common papillary cancer. Other thyroid cancer types, such as follicular cancer, are less commonly found and often have ultrasound features unique to those seen with papillary cancers. Such cancers will require more studies to assess the suitability of TIRADS for their detection. Sixth, the utility of strain elastography in cases with nodular goitre can be controversial due to the very small volume of representative parenchyma, which limits its diagnostic potential, especially for strain ratio, due to insufficient volume of the normal parenchyma. From a technical point of view, independent, absolute parameters determining the tissue stiffness in $\mathrm{m} / \mathrm{s}$ or $\mathrm{kPa}$ in shear wave elastography, which is also more operator independent, could be more useful. Additionally, shear wave could be superior to strain elastography, particularly in struma nodosa cases because the technique requires no normal thyroid tissue for reference. However, evidence in the literature suggests that addition of shear wave elastography to B-mode did not significantly improve diagnostic parameters for the differentiation of thyroid lesions [21].

\section{Conclusions}

Considering the performance of each TIRADS classification evaluated suggests that the Kwak TIRADS classification may be a useful tool in daily practice for 
the evaluation of thyroid cancer in multinodular goitre, particularly to select cases that require biopsy, improving and simplifying decision-making for clinicians. The next steps should include prospective multicentre research including less common types of thyroid cancer, fine-tuning, and use of clear definitions in the lexicon, and development of a universal system for thyroid tumour ultrasonographic evaluation and classification (comprehensive TIRADS variant) with potential for universal, practical application.

\section{Acknowledgments}

This study was supported by Grant N N402 476437 (2009-2012) from the Ministry of Science and Higher Education of Poland.

\section{References}

1. Fagin JA, Mitsiades N. Molecular pathology of thyroid cancer: diagnostic and clinical implications. Best Pract Res Clin Endocrinol Metab. 2008; 22(6): 955-969, doi: 10.1016/j.beem.2008.09.017, indexed in Pubmed: 19041825

2. Koike E, Noguchi S, Yamashita H, et al. Ultrasonographic characteristics of thyroid nodules: prediction of malignancy. Arch Surg. 2001; 136(3): 334-337, indexed in Pubmed: 11231857.

3. Papini E, Guglielmi R, Bianchini A, et al. Risk of malignancy in nonpalpable thyroid nodules: predictive value of ultrasound and color-Doppler features. J Clin Endocrinol Metab. 2002; 87(5): 1941-1946, doi: 10.1210/ jcem.87.5.8504, indexed in Pubmed: 11994321.

4. Horvath E, Majlis S, Rossi R, et al. An ultrasonogram reporting system for thyroid nodules stratifying cancer risk for clinical management. J Clin Endocrinol Metab. 2009; 94(5): 1748-1751, doi: 10.1210/jc.2008-1724, indexed in Pubmed: 19276237.

5. Park JY, Lee HJ, Jang HW, et al. A proposal for a thyroid imaging reporting and data system for ultrasound features of thyroid carcinoma. Thyroid. 2009; 19(11): 1257-1264, doi: 10.1089/thy.2008.0021, indexed in Pubmed: 19754280.

6. D'Orsi CJ, Sickles EA, Mendelson EB, Morris EA, al eA. ACR BI-RADS ${ }^{\circledR}$ Atlas, Breast Imaging Reporting and Data System. In: Radiology ACo. Reston, VA, Reston, VA 2013.

7. Kwak JY, Han $\mathrm{KH}$, Yoon $\mathrm{JH}$, et al. Thyroid imaging reporting and data system for US features of nodules: a step in establishing better stratification of cancer risk. Radiology. 2011; 260(3): 892-899, doi: 10.1148/ radiol.11110206, indexed in Pubmed: 21771959.

8. Russ G, Royer B, Bigorgne C, et al. Prospective evaluation of thyroid imaging reporting and data system on 4550 nodules with and without elastography. Eur J Endocrinol. 2013; 168(5): 649-655, doi: 10.1530/EJE12-0936, indexed in Pubmed: 23416955.

9. Cheng SP, Lee JJ, Lin JL, et al. Characterization of thyroid nodules using the proposed thyroid imaging reporting and data system (TI-RADS). Head Neck. 2013; 35(4): 541-547, doi: 10.1002/hed.22985, indexed in Pubmed: 22514060.

10. Friedrich-Rust M, Meyer G, Dauth N, et al. Interobserver agreement of Thyroid Imaging Reporting and Data System (TIRADS) and strain elastography for the assessment of thyroid nodules. PLoS One. 2013; 8(10): e77927, doi: 10.1371/journal.pone.0077927, indexed in Pubmed: 24205031.

11. Choi YJ, Baek JH, Baek SH, et al. Web-Based Malignancy Risk Estimation for Thyroid Nodules Using Ultrasonography Characteristics: Development and Validation of a Predictive Model. Thyroid. 2015; 25(12): 1306-1312, doi: 10.1089/thy.2015.0188, indexed in Pubmed: 26437963.

12. Maia FFR, Matos PS, Pavin EJ, et al. Thyroid imaging reporting and data system score combined with Bethesda system for malignancy risk stratification in thyroid nodules with indeterminate results on cytology. Clin Endocrinol (Oxf). 2015; 82(3): 439-444, doi: 10.1111/cen.12525, indexed in Pubmed: 24930423.

13. Zhang J, Liu BJ, Xu HX, et al. Prospective validation of an ultrasoundbased thyroid imaging reporting and data system (TI-RADS) on 3980 thyroid nodules. Int J Clin Exp Med. 2015; 8(4): 5911-5917, indexed in Pubmed: 26131184.
14. Park VY, Kim EK, Kwak JY, et al. Thyroid Imaging Reporting and Data System and Ultrasound Elastography: Diagnostic Accuracy as a Tool in Recommending Repeat Fine-Needle Aspiration for Solid Thyroid Nodules with Non-Diagnostic Fine-Needle Aspiration Cytology. Ultrasound Med Biol. 2016; 42(2): 399-406, doi: 10.1016/j.ultrasmedbio.2015.10.011, indexed in Pubmed: 26614385.

15. Migda B, Słapa R, Bierca J, et al. Differentiation of thyroid nodules in multinodular goiter with the application of technical ultrasound advances - initial results. Endokrynol Pol. 2016; 67(2): 157-165, doi: 10.5603/ EP.a2016.0026, indexed in Pubmed: 26884295.

16. Kim EK, Park CS, Chung WY, et al. New sonographic criteria for recommending fine-needle aspiration biopsy of nonpalpable solid nodules of the thyroid. AJR Am J Roentgenol. 2002; 178(3): 687-691, doi: 10.2214/ ajr.178.3.1780687, indexed in Pubmed: 11856699.

17. Chan BK, Desser TS, McDougall IR, et al. Common and uncommon sonographic features of papillary thyroid carcinoma. J Ultrasound Med. 2003; 22(10): 1083-1090, indexed in Pubmed: 14606565.

18. Jarzab B, Dedecjus M, Słowińska-Klencka D, et al. Guidelines of Polish National Societies Diagnostics and Treatment of Thyroid Carcinoma. 2018 Update. Endokrynol Pol. 2018; 69(1): 34-74, doi: 10.5603/ EP.2018.0014, indexed in Pubmed: 29442352.

19. Bartolotta TV, Midiri M, Galia M, et al. Qualitative and quantitative evaluation of solitary thyroid nodules with contrast-enhanced ultrasound: initial results. Eur Radiol. 2006; 16(10): 2234-2241, doi: 10.1007/ s00330-006-0229-y, indexed in Pubmed: 16670868.

20. Nemec U, Nemec SF, Novotny C, et al. Quantitative evaluation of contrastenhanced ultrasound after intravenous administration of a microbubble contrast agent for differentiation of benign and malignant thyroid nodules: assessment of diagnostic accuracy. Eur Radiol. 2012; 22(6): 1357-1365, doi: 10.1007/s00330-012-2385-6, indexed in Pubmed: 22322310.

21. Dobruch-Sobczak K, Zalewska EB, Gumińska A, et al. Diagnostic Performance of Shear Wave Elastography Parameters Alone and in Combination with Conventional B-Mode Ultrasound Parameters for the Characterization of Thyroid Nodules: A Prospective, Dual-Center Study. Ultrasound Med Biol. 2016; 42(12): 2803-2811, doi: 10.1016/j. ultrasmedbio.2016.07.010, indexed in Pubmed: 27623500.

22. Cantisani V, Lodise P, Di Rocco G, et al. Diagnostic accuracy and interobserver agreement of Quasistatic Ultrasound Elastography in the diagnosis of thyroid nodules. Ultraschall Med. 2015; 36(2): 162-167, doi: 10.1055/s-0034-1366467, indexed in Pubmed: 24955842.

23. Bista M, K C T, Regmi D, et al. Diagnostic accuracy of fine needle aspiration cytology in thyroid swellings. J Nepal Health Res Counc. 2011; 9(1) 14-16, indexed in Pubmed: 22929705.

24. Moon HJ, Sung JiM, Kim EK, et al. Diagnostic performance of gray-scale US and elastography in solid thyroid nodules. Radiology. 2012; 262(3): 1002-1013, doi: 10.1148/radiol.11110839, indexed in Pubmed: 22357900.

25. Unlütürk U, Erdoğan MF, Demir O, et al. Ultrasound elastography is not superior to grayscale ultrasound in predicting malignancy in thyroid nodules. Thyroid. 2012; 22(10): 1031-1038, doi: 10.1089/thy.2011.0502, indexed in Pubmed: 22876757.

26. Bojunga J, Herrmann E, Meyer G, et al. Real-time elastography for the differentiation of benign and malignant thyroid nodules: a metaanalysis. Thyroid. 2010; 20(10): 1145-1150, doi: 10.1089/thy.2010.0079, indexed in Pubmed: 20860422

27. Cantisani V, D'Andrea V, Biancari F, et al. Prospective evaluation of multiparametric ultrasound and quantitative elastosonography in the differential diagnosis of benign and malignant thyroid nodules: preliminary experience. Eur J Radiol. 2012; 81(10): 2678-2683, doi: 10.1016/j. ejrad.2011.11.056, indexed in Pubmed: 22357195.

28. Gietka-Czernel M, Kochman M, Bujalska K, et al. Real-time ultrasound elastography - a new tool for diagnosing thyroid nodules. Endokrynol Pol. 2010; 61(6): 652-657, indexed in Pubmed: 21104638.

29. Woliński K, Szczepanek-Parulska E, Stangierski A, et al. How to select nodules for fine-needle aspiration biopsy in multinodular goitre. Role of conventional ultrasonography and shear wave elastography a preliminary study. Endokrynol Pol. 2014; 65(2): 114-118, doi: 10.5603/ EP.2014.0016, indexed in Pubmed: 24802734.

30. Grant EG, Tessler FN, Hoang JK, et al. Thyroid Ultrasound Reporting Lexicon: White Paper of the ACR Thyroid Imaging, Reporting and Data System (TIRADS) Committee. J Am Coll Radiol. 2015; 12(12 Pt A): 1272-1279, doi: 10.1016/j.jacr.2015.07.011, indexed in Pubmed: 26419308.

31. Trzebińska A, Dobruch-Sobczak K, Jakubowski W, et al. Standards of the Polish Ultrasound Society - update. Ultrasound examination of thyroid gland and ultrasound-guided thyroid biopsy. J Ultrason. 2014; 14(56): 49-60, doi: 10.15557/JoU.2014.0005, indexed in Pubmed: 26676167.

32. Ferris RL, Baloch Z, Bernet V, et al. American Thyroid Association Surgical Affairs Committee. American Thyroid Association Statement on Surgical Application of Molecular Profiling for Thyroid Nodules: Current Impact on Perioperative Decision Making. Thyroid. 2015; 25(7): 760-768, doi: 10.1089/thy.2014.0502, indexed in Pubmed: 26058403. 